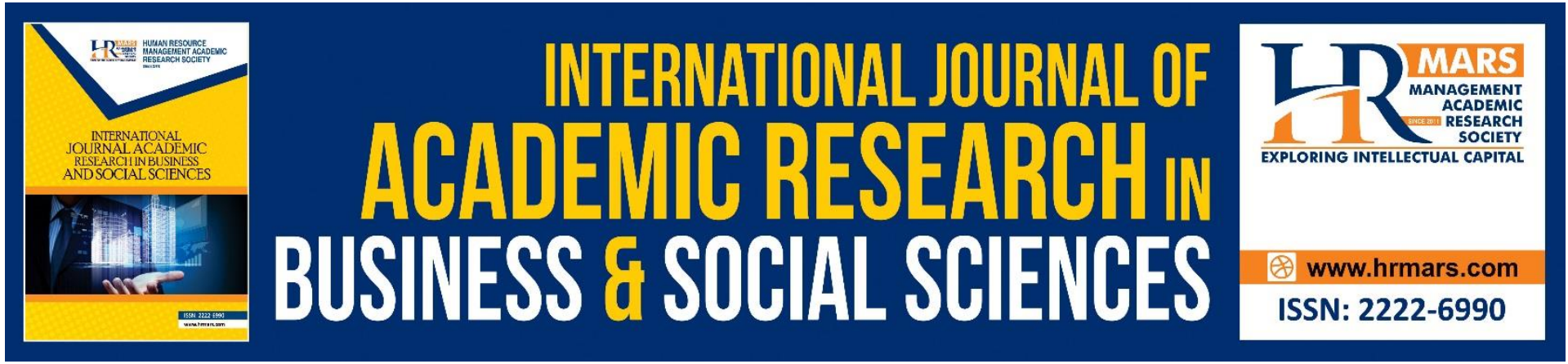

\title{
Application of Rhetoric in The Malay-Language Scholarly Books as a Product Marketing Strategy
}

Nurul Fadzlin Mohd Asri, Sharil Nizam Sha'ri, Rohaidah Kamaruddin, Zaitul Azma Zainon Hamzah, Rozita Che Rodi

To Link this Article: http://dx.doi.org/10.6007/IJARBSS/v11-i8/10729

DOI:10.6007/IJARBSS/v11-i8/10729

Received: 08 June 2021, Revised: 12 July 2021, Accepted: 27 July 2021

Published Online: 10 August 2021

In-Text Citation: (Asri et al., 2021)

To Cite this Article: Asri, N. F. M., Sha'ri, S. N., Kamaruddin, R., Hamzah, Z. A. Z., \& Rodi, R. C. (2021). Application of Rhetoric in The Malay-Language Scholarly Books as a Product Marketing Strategy. International Journal of Academic Research in Business and Social Sciences, 11(8), 275-285.

Copyright: @ 2021 The Author(s)

Published by Human Resource Management Academic Research Society (www.hrmars.com)

This article is published under the Creative Commons Attribution (CC BY 4.0) license. Anyone may reproduce, distribute, translate and create derivative works of this article (for both commercial and non-commercial purposes), subject to full attribution to the original publication and authors. The full terms of this license may be seen at: http://creativecommons.org/licences/by/4.0/legalcode

Vol. 11, No. 8, 2021, Pg. 275 - 285

Full Terms \& Conditions of access and use can be found at http://hrmars.com/index.php/pages/detail/publication-ethics 


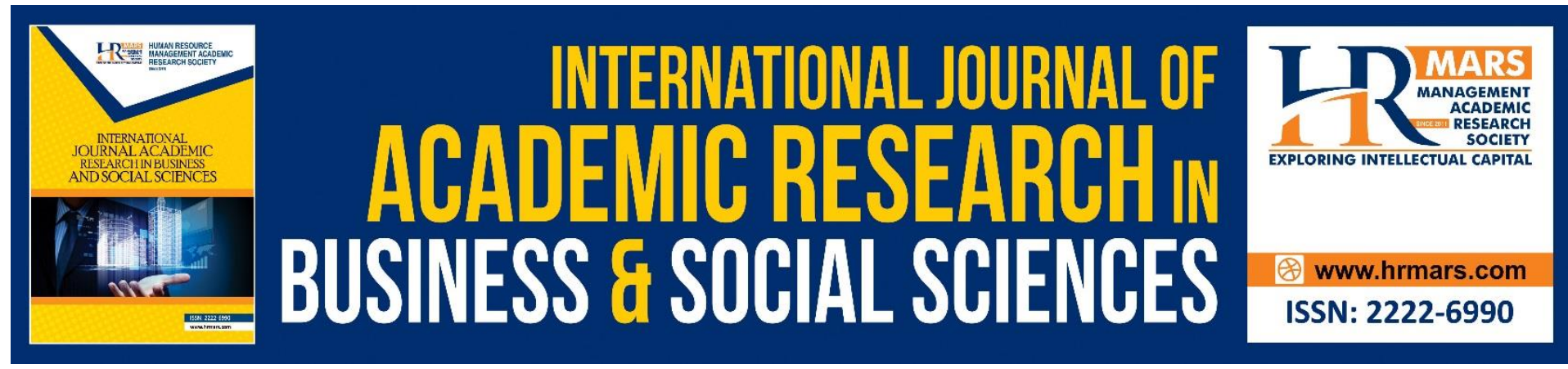

\title{
Application of Rhetoric in The Malay-Language Scholarly Books as a Product Marketing Strategy
}

\author{
Nurul Fadzlin Mohd Asri, Sharil Nizam Sha'ri, Rohaidah \\ Kamaruddin, Zaitul Azma Zainon Hamzah, Rozita Che Rodi \\ Department of Malay Language, Faculty of Modern Languages and Communication \\ Universiti Putra Malaysia, 43400 Serdang, Selangor
}

\begin{abstract}
Rhetoric in the writing of scholarly books published by publishers in public universities and government institutions or the Majlis Penerbitan IImiah Malaysia (MAPIM) is a marketing strategy used upon the society, but is not known to the public. In fact, little academic research has been conducted on the book publishing industry in the country, even though this scholarly genre is proven to record specific expertise and fields to be shared, and at the same time needed by the community. Thus, this study aims to identify the type of rhetoric used in selected Malay-language scholarly books in connection with the marketing strategy practiced by MAPIM Publishers and analyze the use of rhetoric in selected Malay-language scholarly books by applying the Modern Rhetorical Theory (1993) by Enos and Brown. This study uses text analysis methods to analyze rhetoric in scholarly books. This study found three modes of rhetoric, which are, descriptive rhetoric, explosive rhetoric, and argumentative rhetoric have been well-used in the writing of Malay-language scholarly books as a strategy to disseminate knowledge through captivating language and also guarantee effective delivery of information. This is in line with the main objective of MAPIM to ensure that high-quality scholarly books can be offered as a product that meets the needs of the target group as the development of scholarship to the community.
\end{abstract}

Keywords: Rhetoric, Scientific Books, Strategy, Promotion, MAPIM

\section{Introduction}

MAPIM products refer to scholarly books produced by authors based on their field of study, then the results of the study are reported in the form of a neat and systematic text (Hamed, 2001). Therefore, scholarly books need effective rhetoric to change the stance and open the minds of readers to easily understand what is presented by the authors, and simultaneously make the book a quality book and get a place in the hearts of readers (Hussin, 2019).

In this context, the authors ability to use rhetorical elements can produce interesting and effective scholarly writing in terms of explanation, elaboration, argumentation, and persuasion that plays an important role in thoroughly conveying the authors' ideas besides minimizing the editing process at the editorial level before printing and marketing the book to the target group (Ahmad, 2018). 
However, authors' weaknesses in skilfully applying rhetoric in writing disrupts an important element in the world of scholarly book publishing (Samani, 2018). This is because the failure of applying rhetoric will affect the quality of a scholarly book in producing effective writing to interpret diverse fields of knowledge (Hashim, 2019). Readers' interest also cannot be stimulated as authors fail to change readers perception of the reading materials (Nizam, 2019).

Therefore, authors ability to utilize rhetoric can help readers grab the gist of the content, through accurate language delivery along with effective writing techniques. Hence, there is a need to fill the research gap by conducting an experiment to identify the kinds of rhetoric used by the authors of Malay language scholarly books as a strategy to influence their readers.

In the meantime, the Malay-language scholarly books are reported to be lacking in communication. This is due to the adaptation and use of vague terms that eventually fail to serve as a channel to persuade and educate readers from different academic disciplines (Yaakob, 2018). It can lead to the formation of inappropriate meaning and production of poor quality and bland writing (Adnan, 2018).

Therefore, the role of rhetoric becomes an effective strategy to display the use of functional and relevant language in giving arguments and presenting argument support thoughtfully as well as having a profound effect. Hence, a conceptual framework is developed for the purpose of analyzing the use of rhetoric in the selected Malay-language scholarly books. It aims to provide an explanation of the use of rhetoric based on its modes.

Meanwhile, the pattern of scientific scholarly book writing does not create a high purchasing power. As stated by Adnan (2019), a scholarly book presents a specific study and the progress of its market is slow. This is because, high scholarship in the writing of scholarly books does not have a persuasive effect on the purchasing power of the target group in order to maintain the continuity of the publication of the book (Osman, 2017).

Based on that, authors' efficiency in applying a combination of rhetorical modes can change the pattern of scholarly writing to be presented in a form that is more interesting and easily digested by the reader. At the same time, it helps to increase the purchasing power of the target group who love active reading. Therefore, it can be concluded that the effective use of rhetoric in scholarly writing is a strategy to streamline MAPIM products in ensuring the accessibility and comprehensibility of ideas to the target reader.

\section{Objectives}

The objectives of this study are as follows:

1. To identify the rhetorical modes found in the selected Malay-language scholarly books.

2. To analyze the use of rhetorical modes in the selected Malay-language scholarly books using the Modern Rhetorical Theory (1993) by Enos and Brown.

3. To formulate the dominant rhetorical modes based on the principle of marketing of Malay-language scholarly books by MAPIM publication. 


\section{Research Data Processing Based on Each Objective}

The first step taken by the researcher to process the data analysis of the study was to identify the rhetorical modes used in the selected Malay-language scholarly books. The data was gained through the MAPIM publishers catalog which can be accessed virtually for the purpose of identifying the study sample. The best-selling Malay-language scholarly books was the main factor in choosing the study sample. Through this method, the researcher can clearly seek the rhetorical strategy used by the authors that contributes to their books becoming the bestselling.

In the second step, the researcher analyzed the rhetorical modes that have been identified in the selected Malay-language scholarly books by using the Theory of Modern Rhetoric by Enos and Brown (1993) as the basis for the study. The analysis is made based on text passages that clearly show the application of rhetoric by the authors based on the characteristics and concepts of the use of the rhetoric. It aims to explain the meaning behind the application of the rhetorical modes as well as its role in the writing of the scholarly books.

In the last step, the researchers came to a conclusion that rhetoric can be classified as a language art that serves as a persuasive strategy through the use of language symbols manipulated by the authors. Effective rhetoric can coordinate social action in a way that it influences the interest of the readers of scholarly books. Thus, rhetoric can be used as a strategy of writing Malay-language scholarly books as a process of persuading through the use of captivative language that contributes to the welcoming of the scholarly books in the publishing market.

\section{Modern Rhetorical Theory (1993) by Enos and Brown}

As is well known, the use of theory in a study can facilitate the understanding of a complex explanation, (Garrison, 2021). This is because, research theory is a vital element in a study especially to produce a research that can be presented in an orderly manner as well as in a solid and perfect explanation. Thus, the researcher applied the Modern Rhetorical Theory (1993) by Enos and Brown as the basis of this study.

In relevance, the characteristics of modern rhetorical theory can be explained as follows; narrative rhetoric is a type of rhetoric that has a sequence of events presented in a chronological order consisting of themes, questions, characters and characteristics, setting, plot, language style, and point of view; known as the structure of a narrative. This combined structure is summarized in a writing using literary language that is expressive in nature (Leech, 1993).

Descriptive rhetoric is the explanation of an idea that has a complete presentation of facts and information to the reader or listener. The presentation of descriptive rhetoric needs to be objective, accurate, clear and structured, as well as realistic and impressionistic nature. Descriptive rhetorical writing requires a combination of three parts namely introduction, description, and conclusion. It aims to give a more structured and interesting form of language (Tarigan, 1986).

Next, expository rhetoric is the transfer of an idea or information from a person to the audience. The expository rhetoric reveals and displays information with a presentation 
accompanied by definitions and comparative examples. Disclosures are made using descriptive and analytical techniques to explain ideas related to concepts, terms, facts, philosophies, problems, analyzes, processes, and policies that are described accurately, clearly, and in detail (Stott \& Andrews, 2001).

Whereas, argumentative rhetoric emphasizes intellectual and rational features in its argument. This rhetoric is used in academic events or formal-type events along with the support of several other information as concrete evidence. It aims to create a high value of trust in the target reader with deductive and inductive delivery techniques. This is because, a solid argument along with concrete supporting material can stimulate the trust and confidence of the reader (Sabran, 2002).

In addition, persuasive rhetoric emphasizes features that are able to influence the reader to believe what the author is conveying. The language used is persuasive to influence the reader through the use of sentences that are captivating, interesting and emphasizing the subtlety of language. It can also be psychological in nature which consists of rational persuasion and irrational persuasion, that is, complete presentation of facts or persuasion involving emotions (Omar, 2007a).

\section{Justification of Theory Selection}

Modern Rhetorical Theory (1993) by Enos and Brown was chosen because the researcher can conduct a systematic analysis as it provides perspectives that can drive a research towards a particular discipline of knowledge (Talib 2010). Therefore, the rhetorical modes used by the authors of the selected Malay-language scholarly books can be explained in determining the strategy that adopted by the MAPIM publishers for the purpose of improving the quality of knowledge sharing through the products offfered to the target reader.

\section{Findings and Discussion}

This section focuses on the number of rhetorical modes found in the study sample that have been identified one by one based on Figure 1.1, Figure 1.2, and Figure 1.3. The parsing analysis technique is used to obtain the total number of rhetorical applications by the authors of the book as research data. The data obtained provides answer for the first objective of the study by reporting the distribution of the application of rhetorical modes specifically.

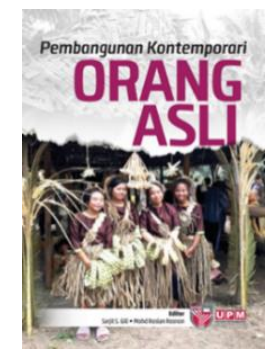

Figure 1.1: Pembangunan Kontemporari Orang Asli 
Table 1.1 Application of Rhetoric Based on Chapters

\begin{tabular}{|c|c|c|c|c|c|c|}
\hline Title & $\begin{array}{l}\text { Chapter } \\
\text { s }\end{array}$ & $\begin{array}{l}\text { Narattiv } \\
\text { e }\end{array}$ & $\begin{array}{l}\text { Description } \\
\mathrm{s}\end{array}$ & $\begin{array}{l}\text { Disclosur } \\
\text { e }\end{array}$ & $\begin{array}{l}\text { Argumentatio } \\
n\end{array}$ & $\begin{array}{l}\text { Persuasio } \\
n\end{array}$ \\
\hline $\begin{array}{l}\text { Pembanguna } \\
\text { n } \\
\text { Kontempora } \\
\text { ri Orang Asli }\end{array}$ & 1 & & $V(5)$ & $\mathrm{V}(12)$ & $V(8)$ & \\
\hline & 3 & & $V(4)$ & $\mathrm{V}(10)$ & $V(5)$ & \\
\hline & 5 & & $V(3)$ & $V(12)$ & $\mathrm{V}(7)$ & \\
\hline & 6 & & $V(5)$ & $\mathrm{V}(11)$ & $\mathrm{V}(15)$ & \\
\hline & 7 & & $V(6)$ & V 11) & $V(9)$ & \\
\hline & 8 & & $V(2)$ & V (9) & $\mathrm{V}(11)$ & \\
\hline & 14 & & $V(3)$ & V (3) & $\checkmark(7)$ & \\
\hline
\end{tabular}

Footnote: Labels ( ) refer to the number of types of rhetorical modes found in each chapter.

Table 1.1 shows the application of rhetoric according to its types. The number listed focuses on three (3) modes of rhetoric only, namely descriptive rhetoric, expository rhetoric, and argumentative rhetoric. The distribution shows that the most frequent application of rhetoric used by the author is expository rhetoric with a total of 68 times, followed by argumentative rhetoric as many as 62 times, and descriptive rhetoric as many as 28 times.

Based on the number of applications recorded, it is clear that the authors have chosen the expository rhetoric as a skill to build a storyline with their own style to present information to the readers of the scholarly book. It coincides with the view of Bakar (2015) that rhetoric is related to a person's proficiency in language, or according to Amir (2019), rhetoric needs to be applied by writers to produce an effective writing.

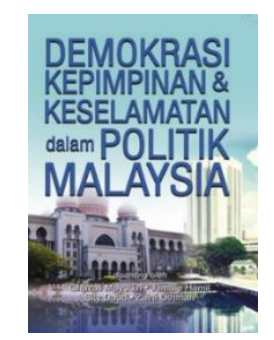

Figure 1.2: Demokrasi Kepimpinan \& Keselamatan dalam Politik Malaysia 
Table 1.2 Application of Rhetoric Based on Chapters

\begin{tabular}{|c|c|c|c|c|c|c|}
\hline Title & $\begin{array}{l}\text { Chapter } \\
\text { s }\end{array}$ & $\begin{array}{l}\text { Narattiv } \\
\text { e }\end{array}$ & $\begin{array}{l}\text { Description } \\
\mathrm{s}\end{array}$ & $\begin{array}{l}\text { Disclosur } \\
\text { e }\end{array}$ & $\begin{array}{l}\text { Argumentatio } \\
n\end{array}$ & $\begin{array}{l}\text { Persuasio } \\
n\end{array}$ \\
\hline $\begin{array}{l}\text { Demokrasi } \\
\text { Kepimpinan } \\
\text { \& } \\
\text { Keselamata } \\
\text { n } \\
\text { Dalam } \\
\text { Politik } \\
\text { Malaysia }\end{array}$ & 1 & & $\checkmark(15)$ & $V(10)$ & $\mathrm{V}(16)$ & \\
\hline & 3 & & $\sqrt{ }(2)$ & $V(10)$ & $\mathrm{V}(26)$ & \\
\hline & 4 & & $V(12)$ & $\mathrm{V}(17)$ & $\mathrm{V}(27)$ & \\
\hline & 9 & & $V(8)$ & $\mathrm{V}(15)$ & $\mathrm{V}(15)$ & \\
\hline & 10 & & V (4) & V 11) & $\mathrm{V}(19)$ & \\
\hline
\end{tabular}

Footnote: Labels ( ) refer to the number of types of rhetorical modes found in each chapter.

Table 1.2 above clearly shows the number of applications of rhetoric according to their modes. The number listed also focuses on three (3) types of rhetorical modes only, namely descriptive rhetoric, expository rhetoric, and argumentative rhetoric. However, the application of rhetoric contained in this book shows a total of 103 times of the argumentative rhetoric. Next, a total of 63 times application of expository rhetoric, and a total of 41 times application of descriptive rhetoric.

Based on this identified amount of rhetoric, the tendency of the application of rhetorical mode in this book is focused on argumentative rhetoric. This shows that the authors' strategy of developing the content of this book is done by highlighting the use of argumentative rhetoric as a creative process that involves intellectualization, organization, and creativity in producing an effective writing. The view of Omar (2007b) states that language strategies can produce interesting writing of scientific papers.

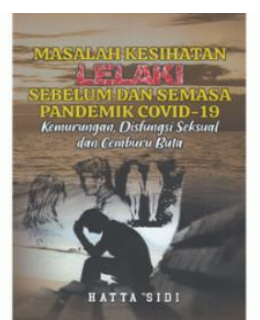

Figure 1.3: Masalah Kesihatan Lelaki Sebelum dan Semasa Pandemik Covid-19 
Table1.3 Application of Rhetoric Based on Chapters

\begin{tabular}{|c|c|c|c|c|c|c|}
\hline Title & $\begin{array}{l}\text { Chapter } \\
\text { s }\end{array}$ & $\begin{array}{l}\text { Narrativ } \\
\text { e }\end{array}$ & $\begin{array}{l}\text { Description } \\
\mathrm{s}\end{array}$ & $\begin{array}{l}\text { Disclosur } \\
\text { e }\end{array}$ & $\begin{array}{l}\text { Argumentatio } \\
n\end{array}$ & $\begin{array}{l}\text { Persuasio } \\
n\end{array}$ \\
\hline Masalah & 1 & & & & & \\
\hline Kesihata & & & & & & \\
\hline $\mathrm{n}$ & & & $V(16)$ & $\mathrm{V}(15)$ & $\vee(5)$ & \\
\hline Lelaki & & & & & & \\
\hline Sebelum & & & & & & \\
\hline dan & & & & & & \\
\hline Semasa & & & & & & \\
\hline Pandemi & & & & & & \\
\hline k Covid- & & & & & & \\
\hline 19 & & & & & & \\
\hline & 2 & & $\sqrt{ }(22)$ & $V(15)$ & $V(18)$ & \\
\hline & 5 & & $v(25)$ & $V(20)$ & $V(15)$ & \\
\hline
\end{tabular}

Footnote: Labels ( ) refer to the number of types of rhetorical modes found in each chapter.

Table 1.3 above clearly shows the number of rhetorical applications according to the types that have been classified. The number listed according to chapters in this book also focuses on three (3) modes of rhetoric only, namely descriptive rhetoric, expository rhetoric, and argumentative rhetoric. A total of 63 applications of descriptive rhetoric were encountered in total. Followed by a total of 50 applications of expository rhetoric, and a total of 38 applications of argumentative rhetoric.

Overall, the book is dominated by the application of descriptive rhetoric to establish a relationship between the author and the reader. The relationship is a strategy articulated by the author to convey thoughts and share experiences with the reader, effectively and perfectly. Thus, the application of this rhetoric should be a must to attract the attention of the reader (Baharom, 2008).

\section{Rhetorical Application Analysis Based on Modern Rhetorical Theory (1993) by Enos and Brown}

This section discusses the analysis of the rhetorical modes that are dominated in the Malaylanguage scholarly books selected for this study. The three (3) most dominant modes of rhetoric representing each scholarly book, namely descriptive rhetoric, expository rhetoric, and argumentative rhetoric will be analyzed descriptively using the Modern Rhetorical Theory (1993) by Enos and Brown. It is seen as desirable to give the reader an understanding of the authors' competence in applying rhetoric in a good writing.

\section{Disclosure}

"Masyarakat orang Asli merupakan golongan etnik minoriti di Malaysia. Masyarakat ini terbahagi kepada tiga kelompok utama dengan 18 suku kaum. Tiga kelompok utama ialah kelompok Melayu-Proto, Senoi dan Negrito (Jabatan Kemajuan Orang Asli, 2011)." 
"The Orang Asli community is an ethnic minority in Malaysia. The community is divided into three main groups with 18 tribes. Three main groups are groups of Proto-Malays, Senoi, and Negrito (Orang Asli Development Department, 2011).

(Pembangunan Kontemporari Orang Asli, p. 2)

Based on the insertion of the passage above, the researcher classifies that the passage contains elements of expository rhetoric based on the characteristics of the passage which emphasizes the form of writing that gives clear exposure to the reader about a matter in more depth and detail. It emphasizes the aspect of diction, thoughtful, and meaningful selection that starts from one piece of information to another piece of information (Phelan, 2017).

This can be seen in the passage above which shows that the expository rhetoric is used to provide a clear exposure to the reader about the background of the indigenous people in Malaysia. The choice of a simple phrase reveals a clear description by the authors for the purpose of influencing the reader (Enos \& Brown, 1993). In other words, the insertion of this passage presents a simple language for the reader to understand and be interested in continuing reading about the history of the indigenous people in Malaysia.

\section{Argumentation}

“... Justeru, untuk meneliti persoalan tersebut, perlunya kepada kupasan takrifan yang lebih khusus terhadap demokrasi. Sebagai penulis, usaha untuk memberikan takrifan terhadap demokrasi akan mengalami permasalahan takrifan atau dikenali juga sebagai dilema takrifan. Apatah lagi dalam ruang yang terhad ini."

(Demokrasi Kepimpinan \& Keselamatan dalam Politik Malaysia, hlm.

"... Therefore, to examine the question, there is a need for a more specific definition of democracy. As a writer, the effort to provide a definition of democracy will be challenged with the problem of defining or also known as the dilemma of definition. Not to mention in this limited space."

(Demokrasi Kepimpinan \& Keselamatan dalam Politik Malaysia, p. 30)

Next, the argumentative rhetoric in the insertion of the passage above applied by the authors can be seen clearly when the authors try to influence the reader to believe and have faith in the truth of the need to know more about the object of discussion. In this passage, it indicates the truth or falsity of an argument. Thus, the more facts used, the stronger the truth is achieved (Dryzek, 2010).

If examined, the insertion of this passage has raised the question of posing an argument for the purpose of convincing the audience about the need to parse a detailed definition regarding democracy. According to Aristotle (1991) a well-argued idea emerges when the idea presented arouses the curiosity of the reader. Therefore, the reader will be interested to continue reading to agree with the ideas suggested by the authors of this book. 


\title{
Descriptions
}

"Encik Badrul yang berumur 43 tahun merupakan seorang eksekutif sebuah syarikat di selatan Terengganu yang telah bekerja selama 10 tahun dan baru dinaikkan pangkat ke jawatan Ketua Eksekutif di syarikat beliau bekerja dan berpindah ke Kuala Lumpur."

(Masalah Kesihatan Lelaki Sebelum dan Semasa Covid-19, hIm. 24)

\begin{abstract}
"Mr. Badrul, who is 43 years old, is an executive of a company in southern Terengganu who has worked for 10 years, and has just been promoted to the position of Chief Executive at the company he worked for and moved to Kuala Lumpur."
\end{abstract}

(Masalah Kesihatan Lelaki Sebelum dan Semasa Covid-19, p. 24)

The author's idea of highlighting the application of descriptive rhetoric can be seen through the elements contained in the insertion of the passage above. This rhetoric provides a visual picture of the main issue to be conveyed (Enos \& Brown 1993). The facts are presented clearly, accurately, and in detail by providing a picture that facilitates the reader to know clearly. It is known as a background reflection of the author's main idea (Gorys, 1989).

Besides that, the use of descriptive rhetoric in the above passage can be seen when the author fully describes the reality of the main subject. The element of observation has been applied by the author to stimulate the interest of the reader to recognize the idea that the author wants to convey. In this regard, the descriptive rhetoric has been utilized by the author of the scholarly books to report on the agenda of knowledge sharing on health issues.

\section{Conclusion}

Overall, only three of the five rhetorical modes have been applied by the authors of the three Malay-language scholarly books selected. The predominant rhetoric in the writing highlighted by the authors of the scholarly book Pembangunan Kontemporari Orang Asli is expository rhetoric, followed by argumentative rhetoric in the scholarly book Demokrasi Kepimpinan \& Keselamatan dalam Politik Malaysi, and descriptive rethoric in the scholarly book Masalah Kesihatan Lelaki Sebelum dan Semasa Pandemik Covid-19.

It can be concluded that rhetoric plays an important role in determining the effectiveness of a scholarly writing as a medium of knowledge delivery to the reader. Writers need to apply rhetorical elements as a strategy to produce a quality scholarly writing. Indirectly, it can help the country's scholarly book industry to be in a position of its own as the high purchasing power of the target group can be maintained.

\section{References}

Journals

Bakar, M. A. (2015). Retorik Pembangunan Sosioekonomi Masyarakat Dalam Laporan Media Cetak. Jurnal Linguistik, 20(1), 010-025.

Hashim. (2019). Perkembangan Jurnal Ilmiah Melayu dalam Kalangan Melayu Watan. Jurnal Melayu, 83(6), 137-152.

Nizam, S. (2019). Retorik dalam Risalah Iklan Makanan Segera di Seksyen 7, Shah Alam, Selangor. Jurnal Kesidang, 1(1), 102-127. 
Osman, Z. (2017). Retorik Penulisan IImiah: Penilaian Berdasarkan Prinsip Kerjasama Grice. International Journal of Language Education and Applied Linguistics, 09(1), 69-83.

\section{Books}

Adnan, H. (2019). Industri Buku di Malaysia: Isu-Isu dan Cabaran. Kuala Lumpur: Penerbit Utusan.

Adnan, H. (2018). Penerbitan dan Pemasaran Buku di Malaysia. Kuala Lumpur: Penerbit Universiti Malaya.

Aristotle. (1991). The Metaphysics. New York: Prometheus Books.

Dryzek, J. S. (2010). Climate-Challanged Society. United Kingdom: Oxford University Press. Enos, T., Brown, S. C. (1993). Defining the New Rhetorics. United States: Sage Publications. Garrison, D. (2021). The Arawack Language of Guiana in Its Linguistic and Ethnological Relations. New Delhi: Lector House Publisher.

Gorys, K. (1989). Buku Argumentasi dan Narasi. Indonesia: Penerbit Gramedia.

Hamid, A. A. (2001). Pengenalan kepada Penulisan Ilmiah. Kuala Lumpur: Penerbit Universiti Teknologi Malaysia.

Hussain, A. (2019). Masuk Ke Dalam Cahaya. Kuala Terengganu: Penerbit Yayasan Islam Terengganu.

Leech N. (1993). Principle of Pragmatics. London: Longman Publications.

Omar, A. (2007). Bahasa iklan perniagaan: satu kajian bahasa retorik. Kuala Lumpur: Dewan Bahasa dan Pustaka.

Omar, A. (1988b). Bahasa Iklan Perniagaan: Satu Kajian Bahasa Retorik. Kuala Lumpur: Dewan Bahasa dan Pustaka.

Phelan, M. (2017). Language File Materials for an Introduction to Language and Linguistic (12th ed). United States: The Ohio State University Press.

Samani, M. C. (2018) Penerbitan: Teori dan Praktis. Sarawak: Penerbit Unimas.

Talib, O. (2010). Aplikasi Penulisan Artikel Jurnal. Kuala Lumpur: PTS Publications.

Tarigan, H. (1986). Pengajaran Prakmatik. Jakarta: Penerbit Angkasa.

Yaakob, A. (2018). Retorik Kewartawanan Melayu. Kuala lumpur: Dewan Bahasa dan Pustaka.

\section{Online Newspaper Articles}

Amir, J. (2019). Buku ilmiah berbahasa Melayu: Melukut di tepi gantang. Sarawak Voice. Retrived from https://sarawakvoice.com/2019/02/04/buku-ilmiahberbahasa-melayu-melukut-di-tepi-gantang/.

Ahmad, N. (2018). Trend pembacaan rakyat capai Sasaran negara maju. Berita Harian. https://www.bharian.com.my/bhplus-old/2017/01/234637/trend-pembacaanrakyat-capai-sasaran-negara-maju.

\section{Magazine Article}

Sabran, R. (2002). Retorik pendedahan dan penghujahan. Pelita Bahasa, 14 (11).

\section{Thesis}

Baharom, S. (2008). Retorik dalam Novel-Novel Abdullah Hussain. (PhD's Thesis, University Putra Malaysia). University Putra Malaysia, Serdang, Selangor. 